\title{
Development of an Enzyme-linked Immunosorbent Assay for Detection of IgM Antibodies to Babesia bigemina in Cattle
}

\author{
Patrícia M Gonçalves Ruiz, Lygia MF Passos/ ${ }^{+}$, Rosangela Z Machado*, \\ José D Lima**, Múcio FB Ribeiro**
}

\begin{abstract}
Escola de Veterinária **Departamento de Parasitologia, Universidade Federal de Minas Gerais, Caixa Postal 567, 30123-970 Belo Horizonte, MG, Brasil *Faculdade de Ciências Agrárias e Veterinárias, Unesp, Jaboticabal, SP, Brasil
\end{abstract}

\begin{abstract}
A crude antigenic preparation of Babesia bigemina was used to develop an ELISA for the detection of IgM antibodies. Optimal dilutions of the antigen, using positive and negative reference sera, were determined by checkerboard titrations. Negative sera from cattle imported from tick-free areas, serum samples collected from infected $\mathrm{B}$. bigemina cattle were used to validate the test. The specificity was $94 \%$ and sensitivity of the ELISA $87.5 \%$. Sera from 385 cattle deriving from areas free from tick-borne diseases, which were submitted to a preimmunization process, were screened by this technique. The ELISA detected seroconversion on the 14th day post-inoculation in animals either infested with Boophilus microplus ticks (infected with B. bigemina), or inoculated with B. bigemina infected blood. Antibody titers decreased after day 33; however, all animals remained positive until the end of the experiment (124 days). The ELISA described may prove to be an appropriate serological test for the detection of IgM antibodies against $\mathrm{B}$. bigemina.
\end{abstract}

Key words: Babesia bigemina - ELISA - IgM

Bovine babesiosis is an economically important tick-transmitted protozoan parasite of cattle in tropical and subtropical areas (McCosker 1981). In Brazil, the two species present are Babesia bigemina and $B$. bovis. The acute infections with Babesia spp. are characterized by a systemic inflammatory response as evidenced by hyperthermia, anemia with concomitant hemoglobinemia, apathy and jaundice, many times leading to death (Wright \& Goodger 1988).

Accurate diagnosis of B. bigemina infection is essential for disease control measures and for epidemiological studies. During the acute phase of babesiosis the direct identification of the causative agent is possible by examination of stained blood smears, however, during early stages of infection detection of Babesia is difficult, due to very low parasitemia levels.

Several serodiagnostic techniques have been developed and applied for the diagnosis of bovine babesiosis (O'Donoghue et al. 1985, Waltisbuhl

Partial financial support: Fapemig and Capes

${ }^{+}$Corresponding author. Fax: +55-31-3499.2080. E-mail: lygia@dedalus.lcc.ufmg.br

Received 28 May 1999

Accepted 14 November 2000 et al. 1987, Böse et al. 1990, Machado et al. 1997), but these are designed to identify chronic infections since they detect IgG antibodies.

Detection of IgM antibodies may help to identify infection of different species of Babesia and therefore it will be useful for epidemiological studies as well as to evaluate the immune response after immunizations.

The aim of this study was to develop an ELISA system for detection of IgM antibodies against $B$. bigemina in cattle.

\section{MATERIALS AND METHODS}

ELISA standartization

Source of B. bigemina - The B. bigemina isolate used in this study was maintained cryopreserved in $10 \%$ dimethyl sulphoxide, in liquid nitrogen (Jaboticabal stock, Machado et al. 1994).

B. bigemina ELISA antigen - Five to six month old calves, free from hemoparasites, were splenectomized and inoculated intravenously with cryopreserved B. bigemina and monitored daily for the presence of parasites by microscopic examination of Giemsa-stained blood smears. Infected blood was collected in an equal volume of Alsever's solution during the peak of parasitemia (40 to $60 \%$ ) that occurred between the 8th and the 10 th days after inoculation. The blood was diluted 1:4 in normal saline and the infected erythrocytes 
subjected to lyses with ammonium chloride (Martin et al. 1971). A 0.8\%-ammonium chloride solution was prepared using pyrogen-free deionised water (Boyle 1968). To each $90 \mathrm{ml}$ of this solution $10 \mathrm{ml}$ of $0.17 \mathrm{M}$ Tris buffer ( $\mathrm{pH} 7.65)$ were added. The final $\mathrm{pH}$ of the buffered ammonium chloride solution was adjusted to 7.4 at room temperature and then it was warmed to $37^{\circ} \mathrm{C}$. Nine volumes of this solution were mixed with one volume of the suspension of infected erythrocytes. The mixture was incubated at $37^{\circ} \mathrm{C}$ for 3 min during which time hemolysis became evident. The mixture was centrifuged at $1,500 \mathrm{~g}$ for $10 \mathrm{~min}$ and the erythrocytefree sediment was washed three times in sterile normal saline. The pellet was resuspended in 5 vols of PBS containing protease inhibitor (1 mM PMSF, $2 \mathrm{mM}$ TPCK and $0.1 \mathrm{mM}$ TLCK). B. bigemina free merozoites were disrupted by freezing/thawing cycles using liquid nitrogen. The supernatant obtained after centrifugation at 12,000 x g for 60 min at $4{ }^{\circ} \mathrm{C}$ was stored at $-20^{\circ} \mathrm{C}$ until required for ELISA (Machado 1991).

Serum bank - To check the specificity of $B$. bigemina, serum samples from 50 Holstein cattle living in tick-free areas were collected before they were imported to Brazil. These sera were considered negative controls. A positive reference group produced by experimental infections consisting of 24 serum samples anti- $B$. bigemina provided by Embrapa, CNPGC, Campo Grande, MS, Brazil, four anti-Babesia bovis and four anti-Anaplasma marginale serum samples (serum bank - DMVP, UFMG, MG, Brazil) was used.

ELISA procedure - The method used was essentially as described by Wilchek and Bayer (1984). The reactions were carried out on polystyrene plates (Costar, USA). One hundred $\mathrm{ml}$ of antigen diluted in sodium bicarbonate-carbonated $0.05 \mathrm{M}$ buffer $\mathrm{pH} 9.6$, were added to each well. After incubation for $18 \mathrm{~h}$ at $4^{\circ} \mathrm{C}$, the excess of antigen was removed by three washes with PBS Tween 80 at $0.05 \%$. The blocking step was carried out using $100 \mu \mathrm{l}$ of PBS casein 5\%, pH 7.6, during $1 \mathrm{~h}$ at $37^{\circ} \mathrm{C}$. Following washing, the plate was incubated at $37^{\circ} \mathrm{C}$ for $60 \mathrm{~min}$, with $100 \mu \mathrm{l}$ of each serum sample diluted in PBS Tween (1:800). Unbound antibodies were removed by washing the plates as described above. One hundred $\mu$ l of monoclonal anti-bovine IgM Biotin Conjugate (Sigma B 0774), diluted in PBS-Tween, were added to each well and the plates incubated for $60 \mathrm{~min}$ and washed. One hundred $\mu \mathrm{l}$ of Avidin-Peroxidase Conjugate (Sigma A 7419) diluted in PBS-Tween were added to each well of the plate. The anti-bovine IgM biotin conjugate (Sigma) was used at a dilution of 1:30,000 and avidin-peroxidase (Sigma) at 1:100,000, according to the manufacturer's rec- ommendation. The plate was washed after incubation for $1 \mathrm{~h}$ at $37^{\circ} \mathrm{C}$, and $100 \mu \mathrm{l}$ of orthophenylenediamine (OPD) substrate solution were added. The reaction was interrupted using sulphuric acid $4 \mathrm{~N}$ (32 $\mu \mathrm{l}$ per well). Absorbances were read using a microplate reader (Sigma) with a filter of $492 \mathrm{~nm}$.

Standardization of assay - The antigen was attached to the solid-phase on microtitre plates at a concentration of $5 \mathrm{ml} \mathrm{ml}^{-1}$ in carbonate buffer, $\mathrm{pH}$ 9.6 and then reacted against bovine immune and negative reference control sera. Optimal dilutions of antigen and positive and negative sera were determined by checkerboard titrations (Woodford et al. 1990). The antigen was tested against the panel of sera of known origin, including 50 "known negative samples" and 24 samples collected in infected B. bigemina cattle. The discriminant absorbance value (cut-off) was determined by the mean absorbance values of the negative group plus two standard deviations (Richardson et al. 1983).

Specificity was defined as the proportion of known negative serum samples detected as negative, and the sensitivity was defined as the proportion of known positive serum samples detected as positive.

B. bigemina serological profile of infected cattle - Sera collected from 385 animals deriving from areas free from tick-borne diseases, which were submitted to a preimmunization process (Lima 1991), were tested in ELISA. Since it is known that differences regarding infectivity, pathogenicity and virulence may occur if strain of B. bigemina are originated from ticks or from blood, both inocula were used to compare the dynamics antibody production in cattle. Animals were divided into two groups - group A: five animals infested with approximately 2,000 larvae of Boophilus microplus infected with B. bigemina and B. bovis and group B: six animals inoculated with blood containing B. bigemina and B. bovis $\left(10^{6}\right.$ infected erythrocytes). All animals were challenged with infected blood (B. bigemina and B. bovis $-10^{6}$ infected erythrocytes) 30 days after the first inoculation/ infestation. During the first 19 days, tail blood smears were examined daily for parasitemia determination (at least 100 fields were examined under the microscope). After this period, parasitemia was determined every week. Serum samples were collected daily during 19 days after inoculation and thereafter weekly during 15 weeks. Statistical analysis of serological data (absorbance values) was carried out using the Mann Whitney Wilcoxon test (Stell \& Torrier 1960).

\section{RESULTS}

Standardization of assay - Checkerboard titrations showed a dilution of 1:2,000 (5 $\mu \mathrm{g}$ antigen 
$\mathrm{ml}^{-1}$ in carbonate buffer, $\mathrm{pH}$ 9.6) as optimum for the antigen. Serum samples were diluted at 1:800. The mean absorbance value of negative sera was $0.048 \pm 0.038$, resulting in a calculated cut-off value of 0.124. Absorbance values observed with antiA. marginale and anti-B. bovis sera were lower ( $\leq$ $0.071)$ than the calculated cut-off value. The mean absorbance value of the anti- $B$. bigemina serum group was approximately 7.2 times greater than that obtained with pre-infection sera, clearly discriminating between the mean absorbances of the positive and negative reference sera. This data gave a specificity of $94 \%$, with only three among 50 "known negative samples" being detected as positive. Three among 24 anti-B. bigemina sera collected after experimental inoculation with infected B. bigemina blood were detected as negative, giving the assay a sensitivity of $87.5 \%$. The medians of the absorbance values ${ }^{-1}$ of serum samples from the animals submitted to the preimmunization process are shown in the Figure.

Serologic profile of B. bigemina - Parasitemia in blood smears was detected two to four weeks after either B. microplus larva infestation (group A) or inoculation of blood (group B).

The detection of IgM anti-B. bigemina antibodies occurred 14 days p.i. in the animals infected with B. microplus larvae and 19 days p.i. in animals inoculated with infected blood (Figure). A progressive increase in titers was observed up to 26 days p.i., and all the animals proved positive. The challenge given on day 30 p.i. evoked a rapid IgM response up to the 33rd day, when there was a progressive decline in antibody levels. All the ani- mals remained positive, until the end of the experiment at 124 days (Figure). The highest absorbance values for $B$. bigemina were recorded between days 26 and 33 p.i. Significant differences were recorded for the antibody production of the two types of inoculum ( $p>0.05)$ from the 19th to the 68th days p.i. No significant differences were found in the other post-inoculation periods.

\section{DISCUSSION}

The developed ELISA system proved to have sensitivity, allowing the detection of specific IgM antibodies against $B$. bigemina in cattle experimentally infected with $B$. bigemina. Such test has a potential use as diagnostic tool in detecting early seroconvertion of infected animals, as described for B. bovis (Gonçalves et al. 1999).

The kinetics of IgM antibodies in B. bigemina infections reported in the present study differs from that described by O'Donoghue et al. (1985), who found the first antibodies seven days after experimental infection with a cryopreserved stabilate. These authors report a maximum production of antibodies occurring between 12 and 22 days p.i. with a decrease to low levels around 28 days p.i. The differences between their results and the ones reported here are probably related to the fact that their study was based on a single animal, while in the present study a large number of animals was evaluated. The pattern of antibody production differs among the animals. The overall seroconversion occurred around day 14 p.i.

The diagnosis of bovine babesiosis by blood smear examination during the acute phase is lim-

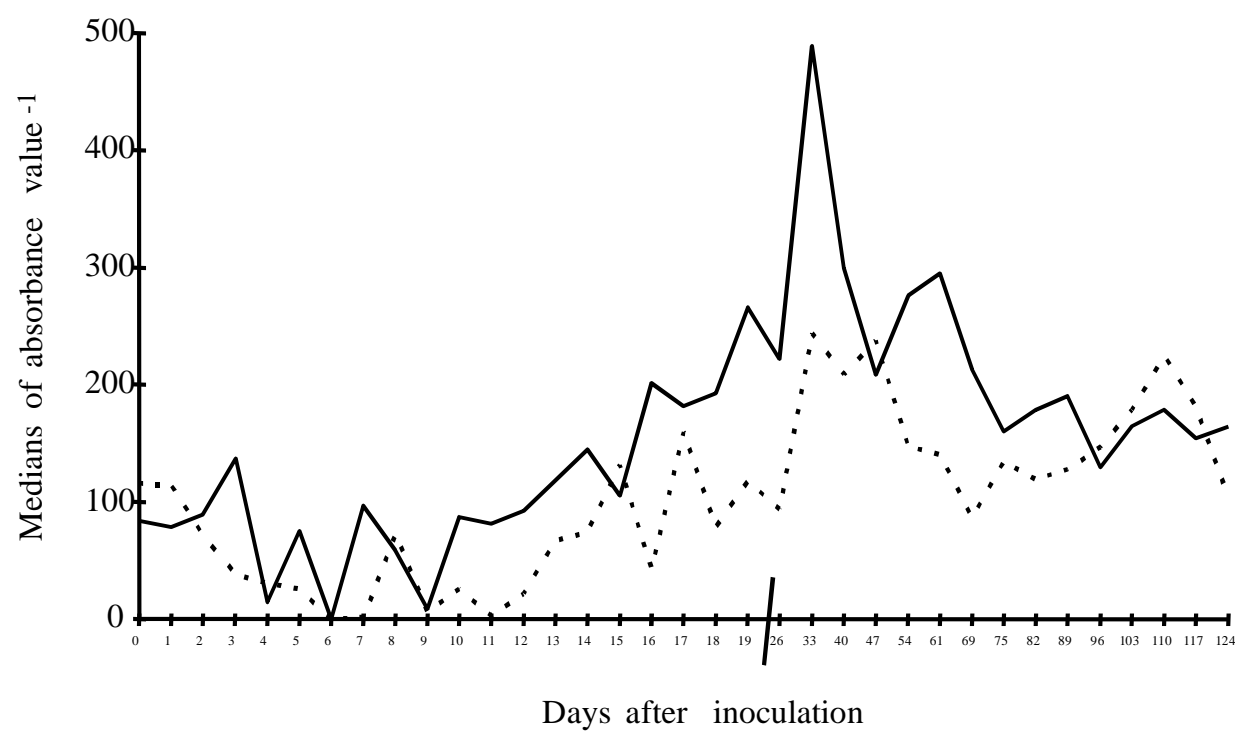

Medians of Elisa absorbance values ${ }^{-1}$ of bovine sera collected during a preimmunization process and tested against Babesia bigemina antigen. — B. bigemina and B. bovis infected Boophilus microplus larvae; - • Babesia bigemina and B. bovis 
ited not only due to the low parasitemias, generally observed at the beginning of infections, but also because a reduced number of samples can be examined in a day. An IgM-ELISA system makes possible the diagnosis at an early stage, which coincides with the beginning of parasite multiplication, contributing to the success of treatment.

Good crude antigenic preparations of intracellular parasites are difficult to produce, particularly due to the presence of host contaminant components, such as red blood cell fragments. These contaminants make the standardization of immunological assays a crucial step (Mahoney \& Goodger 1981) since they increase the occurrence of nonspecific reactions (Böse et al. 1990). El-Ghaysh et al. (1996) suggest that the use of ELISA for $B$. bigemina is inappropriate unless purified antigens or specific monoclonal antibodies are used. The use of semi-defined antigens has allowed the standardization of the ELISA for detection of anti- $B$. bigemina antibodies with good repeatability of results (O'Donoghue et al. 1985). In the present paper the antigenic preparation was produced using a very simple methodology, which requires little material manipulation at a very low cost. The infected red blood cells were lysed with ammonium chlorite, according to the method described by Martin et al. (1971), resulting in B. bigemina merozoites free from red blood cell membranes. In addition the merozoites kept their structural integrity, following the same results obtained by Machado et al. (1994).

In conclusion, the developed ELISA for detection of anti-B. bigemina IgM antibodies shows to be an appropriate test for epidemiological studies in endemic areas as well as in evaluating the antibody response of cattle after immunizations.

\section{REFERENCES}

Böse R, Jacobson RH, Gale KR, Waltisbuhl DJ, Wright IG 1990. An improved ELISA for the detection of antibodies against Babesia bovis using either a native or a recombinant $B$. bovis antigen. Parasitol Res 76: 648-652.

Boyle W 1968. An extension of the 51 Cr-release assay for the estimation of mouse cytotoxins. Transplantation 6: 761-764.

El-Ghaysh A, Sundquist B, Christensson DA, Hilali M, Nassar AM 1996. Observations on the use of ELISA for detection of Babesia bigemina specific antibodies. Vet Parasitol 62: 51-61.
Gonçalves PM, Passos LMF, Ribeiro MFB 1999. Detection of IgM antibodies against Babesia bovis in cattle. Vet Parasitol 82: 11-17.

Lima JD 1991. Premunição: uma alternativa para o controle da Tristeza Parasitária. Seminário Brasileiro de Parasitologia Veterinária, São Paulo, p. 39-43.

Machado RZ 1991. Estudo de Imunidade Celular $e$ Humoral na Babesiose Bovina, PhD Thesis, UNESP, Jaboticabal, 150 pp.

Machado RZ, Montassier HJ, Pinto AA, Lemos EG, Machado MR, Valadão IF, Barci LG, Malheiros EB 1997. An enzyme-linked immunosorbent assay (ELISA) for the detection of antibodies against $\mathrm{Ba}$ besia bovis in cattle. Vet Parasitol 71: 17-26.

Machado RZ, Valadão CAA, Melo WR, Alessi AC 1994. Isolation of Babesia bigemina and Babesia bovis merozoites by ammonium chloride of infected erythocytes. Brazilian J Med Biol Res 27: 25912598.

Mahoney DF, Goodger BV 1981. The isolation of $\mathrm{Ba}$ besia parasites and their products from the blood. In M Ristic, JP Kreier (eds), Babesiosis, Academic Press, New York, p. 323-332.

Martin WJ, Finerty J, Rosenthal A 1971. Isolation of Plasmodium berghei (malaria) parasites of ammonium choride lysis of infected erythrocytes. Nature New Biol 67: 260-261.

McCosker PJ 1981. The global importance of babesiosis. In M Ristic, JP Krier (eds), Babesiosis, Academic Press, New York, p. 1-24.

O’Donoghue KT, Friedhoff OG, Vizcaino OG, Weyreter $\mathrm{H}$ 1985. The detection of IgM and IgG antibodies against Babesia bigemina in bovine sera using semidefined antigens in enzyme immunoassays. Vet Parasitol 18: 1-12.

Richardson MD, Turner A, Warnock DW, Llewellyn PA 1983. Computer-assisted rapid enzyme-linked immunossorbent assay (ELISA) in the serological diagnosis of aspergillosis. J Immunol Meth 9: 57-562.

Stell RGD, Torrier JH 1960. Principles and Procedures of Statistics, McGraw-Hill Book Company, New York, $481 \mathrm{pp}$.

Waltisbuhl DJ, Goodger BV, Wright IG, Commins MA, Mahoney DF 1987. An enzyme-linked immunosorbent assay to diagnose Babesia bovis infection in cattle. Parasitol Res 73: 126-131.

Wilchek M, Bayer EA 1984. The avidin-biotin complex in immunology. Immunol Today 5: 39-43.

Woodford JD, Jones TW, Rae PF, Boid R, Bell-Sakyi L 1990. Seroepidemiological studies of bovine babesiosis on Pemba Island, Tanzania. Vet Parasitol 37: 175-184.

Wright IG, Goodger, BV 1988. Pathogenesis of babesiosis. In M Ristic, Babesiosis of Domestic Animals and Man, Academic Press, New York, p. 99-118. 